Uşak Üniversitesi Sosyal Bilimler Dergisi

$2014,7(1), 217-229$

\title{
Sosyal Bilgiler Etkinliklerinin Eleştirel Düşünmeye Uygunluğu
}

M. Kaan DEMIR*

Tugay TUTKUN*

Çavuş ŞAHİN***

Salih Z. GENÇ

\section{Özet}

Eğitim sistemimiz gerek siyasi, gerek bilimsel-teknolojik, gerekse de sosyal açılardan dünyada ve ülkemizde yaşanan dönüşümlere uyum sağlamak amacıyla yapılan değişikliklere alışkın durumdadır. 2005-2006 Öğretim yılı Türk Eğitim Sisteminde önemli bir değişimin başlangıcını oluşturmuştur. Bu değişimin temeli ise öğretim programlarında yapılan kapsamlı hazırlıkların uygulanmaya başlamasıdır. Sınıf öğretmeni adaylarının ilköğretim 4. ve 5. sınıf sosyal bilgiler etkinliklerinin eleştirel düşünmeye uygunluğuna ilişkin görüşlerini ortaya koymayı amaçlayan bu çalışma tarama modelinde gerçekleştirilmiştir. Çanakkale Onsekiz Mart Üniversitesi Eğitim Fakültesi İlköğretim Bölümü Sınıf Öğretmenliği Anabilim Dalı öğrencileri üzerinde yürütülen araştırmada "Watson-Glaser Eleştirel Akıl Yürütme Gücü Testi” ve Semiz (2011) tarafından geliştirilen "Etkinlikler için Eleştirel Düşünmeye Uygunluk Ölçeği” kullanılmıştır. Elde edilen veriler incelendiğinde sınıf öğretmeni adaylarının 4. ve 5. sınıf çalışma kitaplarındaki etkinlikleri eleştirel düşünmeye "orta düzeyde uygun" olarak değerlendirdikleri, 4. sınıfta "Geçmişimi Öğreniyorum" ünitesinin, 5. sınıfta ise "Bölgemizi Tanıyalım" ünitesinin sınıf öğretmeni adaylarına göre diğer ünitelerden daha çok eleştirel düşünmeyi desteklediği anlaşılmıştır.

Anahtar Kelimeler: Sosyal bilgiler, ilköğretim, eleştirel düşünme, etkinlik.

\footnotetext{
* Doç. Dr., Çanakkale Onsekiz Mart Üniversitesi, Eğitim Fakültesi, İlköğretim Bölümü

** Öğr. Gör. Dr., Çanakkale Onsekiz Mart Üniversitesi, Eğitim Fakültesi, Eğitim Bilimleri Bölümü

*** Doç. Dr., Çanakkale Onsekiz Mart Üniversitesi, Eğitim Fakültesi, İlköğretim Bölümü

**** Doç. Dr., Çanakkale Onsekiz Mart Üniversitesi, Eğitim Fakültesi, İlköğretim Bölümü
} 


\title{
Eligibility of Social Studies Course Activities for Critical Thinking
}

\begin{abstract}
Our education and political system are accustomed to both scientific and technological, as well as the social aspects of the changes made in order to adapt to the transformations in the world. The beginning of a significant change in the academic year 2005-2006 has established in Turkish Education System. The basis of this change is to be implement the extensive preparations in the curriculum. Survey method is used in this research which aims to put forth elementary school candidate teachers' opinions about $4^{\text {th }}$ and $5^{\text {th }}$ grade social studies course activities for consideration. Research is administered at the Department of Elementary School Education with elementary school candidate teachers at Çanakkale Onsekiz Mart University. "Watson-Glaser Critical Thinking Appraisal Test" and "Scale for the Eligibility of Activities for Critical Thinking" developed by Semiz (2011) are used to gather data. Analysis of the data revealed that candidate teachers' assessed the eligibility level of activities in $4^{\text {th }}$ and $5^{\text {th }}$ graders' course books as moderate. Units of "I Learn My Past" in $4^{\text {th }}$ graders' and "Lets Recognize Our Region" in $5^{\text {th }}$ graders' course books are assessed more eligible for critical thinking than others.
\end{abstract}

Key Words: Social studies, primary education, critical thinking, activity

\section{Giriş}

Eğitim sistemimiz gerek siyasi, gerek bilimsel-teknolojik, gerekse de sosyal açlardan dünyada ve ülkemizde yaşanan dönüşümlere uyum sağlamak amacıyla yapılan değişikliklere alışkın durumdadır. 2005-2006 Öğretim yılı Türk Eğitim Sisteminde önemli bir değişimin başlangıcını oluşturmuştur. Bu değişimin temeli ise öğretim programlarında yapılan kapsamlı hazırlıkların uygulanmaya başlamasıdır.

\section{Eleştirel Düşünme ve Sosyal Bilgiler}

MEB Talim ve Terbiye Kurulu Başkanlığınca 2003 yılından itibaren bilgi toplumunun gerekleri, teknolojik gelişmeler, eğitim biliminde öğretme/öğrenme anlayışındaki görüşler ve ülke şartları dikkate alınarak eğitim ve öğretim programlarında reform niteliğinde önemli değişiklikler gerçekleştirilmiştir. Yeni yaklaşımda bilişsel ve yapılandırmacı öğrenme anlayışı benimsenmiş olup kazanım odaklı, etkinlik temelli ve kullanım ağırlıklı bir yöntem geliştirilmiştir. Bu yolla öğrencilerin öğrenme süreci içerisinde daha aktif ve takım ruhunu benimsemiş olmaları, soran, sorgulayan, gerektiğinde tartışan, eleştiren, düşünen, üreten ve paylaşan bir tavır sergilemeleri, öğrenmeyi öğrenen ve karşılaştıkları problemleri kendi 
çabalarıyla çözebilen özelliklere sahip olmaları beklenmektedir (http://tkb.meb.gov.tr/haberayrinti.aspx?sayfa=1\&kod=40). Şüphesiz ki uzun vadeli bir yatırım olan eğitimin çıktılarının bu beklentileri karşılayıp karşılamadığı henüz anlaşılması zor bir durumdur.

Balım ve diğerleri (2009)' un aktardığına göre öğrenme ortamlarında bireyin aktif katılımının gerekliliğini vurgulayan ve öğrenmenin nasıl gerçekleştiğini açıklamaya yönelik öğrenci merkezli yaklaşımlar, son yıllarda öğretim programlarında yerini almıştır. Söz konusu yaklaşımlardan biri de yapılandırmacı yaklaşımdır. Yapılandırmacılık öğrenenin bilgiyi, bireysel ve sosyal olarak kendisinin yapılandırdığını kabul eden bir yaklaşımdır (Özden, 2005). Yapılandırmacılık son yirmi yılda eğitimcilerin dikkatlerini çeken bir öğrenim yaklaşımıdır ve bu yaklaşıma ilişkin çalışmalar hızlı bir şekilde artmaktadır (Phillips, 1995; Al-Weher, 2004). Yapılandırmacı yaklaşımda öğrenme, bilgilerin bireye özgü biçimde anlamlandırılması ve yorumlanması olduğundan her bireyin bilgileri yapılandırma biçimi farklılık göstermektedir (Oğuz, 2004). Yeni bilgi, deneyimler yoluyla bireyler tarafından dünya ile ilişkileri sonucunda yaratılır ve yapılandırılır (Hendry, Frommer ve Walker, 1999). Yapılandırmacı yaklaşımda öğretmenin rolü; öğrencilerin bilgiyi yapılandırmalarında onlara uygun ortamlar sağlayan bir yönlendirici olmaktır (Taber, 2000). Kroll (2004)'e göre; eğitim ve öğretim süreci yapılandırmacı ve gelişimsel görüşü temel alan bir öğretmen eğitim programının içerisinde, öğretmen adayları yapılandırmacı yaklaşıma ilişkin görüşlerini geliştirmelidir. Öğretmenlerin öğrencilerin bilgilerinin yapılandırmalarına aracılık etmelerinin yollarından birisi de ders kitaplarına paralel olarak hazırlanan etkinliklerdir.

Etkinlik, öğretim programlarında belirlenen kazanımları gerçekleştirmeye yönelik, öğretmenlerinin rehberliğinde öğrenciler tarafından yapılan çeşitli eğitsel çalışmalardır. Öğretim programında yer alan etkinlikler öneri ve örnek niteliğindedir. Kılavuz kitapta bulunan ve öğrenme alanlarına göre sınıflandırılmış etkinlikler ise öğretmene sınıf içi bir etkinliğin nasıl planlanması gerektiği konusunda yardımcı olmaktadır. Programda etkinlikler bir öğrenme alanındaki tek kazanıma dönük olabileceği gibi birkaç kazanıma yönelik de olabilir. Bunun yanında öğretmenin, çevre şartlarına, okulun imkânlarına ve öğrencilerin özelliklerine göre belirlenen kazanımları gerçekleştirmeye yönelik ek etkinlikler düzenlemesine de olanak verilmektedir (Temur, 2007: 361).

Sınıf içi etkinlikler uygulanırken öğretmenlerden beklenenler şunlardır; öğrenci özerkliğini ve girişimciliğini destekleme, öğretimde çeşitli ortam, materyal, veri ve birincil bilgi kaynaklarını kullanma, öğrenmeyi 
toplumsal deneyimler sağlayacak şekilde organize etme, bir öğrenme görevini oluştururken gerçek yaşamda karşılaşılan düzeyde karmaşık olmasına dikkat etme, bir öğrenme görevini oluştururken "belirlemek", "karşılaştırmak", "sınıflamak", "çözümlemek", "oluşturmak" gibi üst düzey bilişsel etkinlikleri gerektiren görevlere ağırlık verme, bir öğrenme görevi oluştururken doğrudan parçalara ayırmak yerine öncelikle bütüncül olarak tasarlama, öğrenenlere açık uçlu, düşündürücü, anlamlı ve derinliği olan sorular sorma, onları konuyu araştırmaları için destekleme, aynı zamanda öğrencilere kendi arkadaşlarına sorular sormaya yönlendirme, öğretim sırasında öğrenme döngüsü modeli (keşfetme, kavramı tanıtma, uygulama) kullanarak öğrencilerin doğal merakını besleme, öğrenci tepkilerine göre dersi yönlendirme, gerekli olduğunda öğretim stratejilerini ve içeriği değiştirme, öğrencilerin ilgilerini çekecek sorunlar ortaya atma, öğrencilerin hem öğretmenle hem diğer öğrencilerle etkileşimini destekleme, öğrencilerin yaptıkları hataları anlamaları için geri bildirim kullanma, öğrencilere bir soru yönelttiğinizde olası bir yanıt üzerinde düşünmeleri için yeterince bekleme suresi tanıma, öğrencilere sunulan bilgiler arasında bağlantı kurabilmeleri ve çeşitli görüşleri birbirleriyle karşılaştırabilmeleri için zaman verme ve öğrencilerin başarısını öğrenme bağlamına göre değerlendirme (MEB, 2005: 105 ). Bu beklentilere bakıldığında etkinliklerin eleştirel düşünme ve onun alt boyutlarıyla büyük oranda çakıştığı görülmektedir.

Demir (2006: 25)'in aktardığına göre eleştirel düşünme; insanların problemleri çözmede kullandıkları zihinsel süreçler, stratejiler ve sunumlar (Sternberg, 1999: 46), olguları analiz etme, düşünce üretme ve onu örgütleme, görüşleri savunma, karşılaştırmalar yapma, çıkarımlarda bulunma, tartışmaları değerlendirme ve problem çözme yeteneği (Chance, 1986: 236), problem çözme, çıkarımları belirleme, olasılıkları hesaplama ve kararlar vermeyi gerektiren amaçlı, mantıklı ve hedefe yönelmiş düşünme (Halpern, 1989: 5), kendi düşünce süreçlerimizin bilincinde olarak, başkalarının düşünce süreçlerini göz önünde tutup, öğrendiklerimizi uygulayarak, kendimizi ve çevremizde yer alan olayları anlayabilmeyi amaç edinen etkin ve organize zihinsel bir süreçtir (Cüceloğlu, 1995: 211). Demir (2006: 34)'in aktardığına göre tanımlanmasında çok sayıda farklılığa ve çeşitliliğe rastlanılan eleştirel düşünmenin hangi becerilerden oluştuğu konusunda da birbirinden farklı bakış açları ve yaklaşımlar söz konusudur. Eleştirel düşünmenin tanımlanmasındaki karmaşıklığı gidermede önemli bir paya sahip olan ve Facione başkanlığında yürütülen Delphi Projesi, eleştirel düşünmenin hangi becerileri kapsadığı konusunda da kapsamlı bir açıklama getirmiştir. Delphi Projesi' ne katılan uzmanlar, iyi eleştirel düşünmenin bir beceri boyutunu bir de eğilim boyutunu kapsadığını ortaya koymuşlardır. 
Uzmanlar, eleştirel düşünmenin yorumlama, analiz, değerlendirme, çıkarım, açıklama ve öz düzenleme bilişsel becerilerini kapsadığını belirtmişlerdir. $\mathrm{Bu}$ altı becerinin her biri eleştirel düşünmenin merkezinde, özündedir (Facione, 1990: 4). Bu becerileri öğrencilere kazandırmak için de öncelikle soyut işlem dönemine geçmiş bireylere verilen dersler ön plana çıkmaktadır. Bu derslerden birisi de sosyal bilgiler dersidir.

2005 Sosyal Bilgiler Öğretim Programı'nın "Programın Yapısı-Beceri Nedir?" başlığı altında şu ifadelere yer verilmiştir: "Sosyal bilgiler programı, ilköğretim 4.-8. sınıf düzeyinde diğer derslerle birlikte ilk dokuz beceriyi kazandırmanın yanında, kendine özgü altı beceriyi kazandırmayı da amaçlamaktadır. Bu beceriler şunlardır: Eleştirel düşünme becerisi, yaratıcı düşünme becerisi, iletişim becerisi, araştırma becerisi, problem çözme becerisi, karar verme becerisi, bilgi teknolojilerini kullanma becerisi, girişimcilik becerisi, Türkçe' yi doğru, güzel ve etkili kullanma becerisi, gözlem becerisi, mekânı algılama becerisi, zaman ve kronolojiyi algılama becerisi, değişim ve sürekliliği algılama becerisi, sosyal katılım becerisi ve empati becerisi (MEB, 2005: 52). Görüldüğü gibi 2005 Sosyal Bilgiler Öğretim programında ilk hedef alınan beceri eleştirel düşünme becerisidir.

Etkinlikler, bilişsel üst düzey becerilerin kullanılmasını gerektirir. Etkinlikler, paylaşımcı ve işbirlikçi çalışma ortamlarında yürütülmelidir. Paylaşım ve tartışmaların amacı, var olan bilgilerin yansıtma yöntemiyle paylaşılmasını sağlamak, yeni bilgilerin oluşturulmasını yani kavramsal farklılığın oluşturulmasını kolaylaştırmaktır. Etkinlikler çeşitlilikleri ve farklılıkları ile ortamı zenginleştirirler. Yapılandırmacı kuramda etkinlik ve öğrenilecek bilgi iç içedir: bilginin belli bir problemi çözerken kazanıldığ veya üretildiği kabul edilmektedir, bilginin sunumu söz konusu değildir. Bu kuramın önerdiği öğrenme-öğretme etkinliklerinin özellikleri, içeriğin ne gibi bilgilerden oluşacağı veya bu kuramın içeriğe bakış açısı hakkında ipuçları da vermektedir (Jonassen, 1999: 218; Aktaran: Coşkun, 2008).

$\mathrm{Bu}$ araştırmada problem olarak "sınıf öğretmeni adaylarının 4. ve 5. sınıf sosyal bilgiler ders etkinliklerinin eleştirel düşünmeye uygunluğu hakkındaki görüşleri" ni ortaya çıkarmak temel alınmıştır. Araştırmanın yapıldığı süreçte henüz ülkemizde $4+4+4$ değişiklikleri olarak bilinen uygulamalar başlamadığından sınıf öğretmenlerinin 5. sinıflarda görev yapma uygulaması devam etmekteydi. Araştırmaya öğretmen adaylarının alınma gerekçesi ise mevcut görev yapan öğretmenlere göre son programla ilgili olarak donanımlı yetişmeleridir. Bu problem doğrultusunda da sınıf öğretmeni adaylarının görüşlerinin cinsiyet (K-E), üniversiteye giriş puanı açısından dâhil oldukları öğretim türü (normal öğretim-ikinci öğretim) açısından anlamlı bir farklılık oluşturup oluşturmadığı ve hangi ünite 
etkinliklerinin eleştirel düşünmeyi daha çok desteklediği incelenmeye çalışılmıştır.

\section{Yöntem}

\section{Araştırmanın Modeli}

$\mathrm{Bu}$ araştırma tarama modelinde bir araştırma olarak düzenlenmiştir. Yani araştırmada "ilköğretim 4. ve 5. sınıf sosyal bilgiler etkinliklerinin eleştirel düşünmeye uygunluğu hakkında sınıf öğretmeni adaylarının görüşleri" var olduğu şekliyle ortaya konulmaya çalışılmıştır.

\section{Evren-Örneklem}

Araştırmanın evreni Çanakkale Onsekiz Mart Üniversitesi Eğitim Fakültesi İlköğretim Bölümü Sınıf Öğretmenliği ABD’ nda öğrenim gören 3. sinıf öğrencilerinden (186 öğrenci) oluşmaktadır. 3. sınıf öğrencileri henüz öğretmenlik uygulaması derslerini almamış olsalar bile uygulama bazında etkinliklerin değerlendirilmesi amaçlanmadığından bu durum uygun görülmüştür. Bu doğrultuda bahar yarıyılı sonunda (sosyal bilgiler öğretimi dersini almış) anabilim dalında öğrenim gören sınıf öğretmeni adaylarından 172' sine ulaşılmış ve eleştirel düşünme becerileri "Watson-Glaser Eleştirel Akıl Yürütme Gücü Testi" yardımıyla ölçülerek araştırmaya dâhil edilecek sınıf öğretmeni adayları (146) belirlenmiştir. Böylece araştırmanın örneklemi 146 sınıf öğretmeni adayından oluşmuştur. Öğretmen adaylarının eleştirel düşünme becerilerinin düzeyini ölçmenin amacı sosyal bilgiler etkinliklerinin eleştirel düşünmeye uygunluğunu değerlendirip değerlendiremeyeceklerini ortaya çıkarmaktır.

Toplam 100 sorudan oluşan ve her bir doğru cevabın "1 puan" la kodlandığ 1 ölçekte "50 puan" örnekleme alınacak sınıf öğretmeni adaylarını belirlemede alt puan olarak alınmış ve 50 puanın altında puan alan sınıf öğretmeni adayları araştırmaya dâhil edilmemiştir. Bu şekilde 172 sınıf öğretmeninin \%15' inin yani $26^{\prime}$ sının 50 puan altında bir eleştirel düşünme puanı alması da dikkate değer bir durumdur.

Tablo 1-2' de örneklemi oluşturan sınıf öğretmeni adaylarına ait bilgiler verilmiştir.

Tablo 1: Sınıf Öğretmeni Adaylarının “Cinsiyet” Değişkenine Göre Durumu

\begin{tabular}{lcc}
\hline Cinsiyet & f & \% \\
\hline K & 74 & 50,7 \\
E & 72 & 49,3 \\
TOPLAM & 146 & 100,0 \\
\hline
\end{tabular}


Tablo 1 incelendiğinde araştırmaya katılan sınıf öğretmeni adaylarının cinsiyet açısından birbirine eşit bir dağılım oluşturduğu belirtilebilir.

Tablo 2: Sinıf Öğretmeni Adaylarını “Öğretim Türü” Değişkenine Göre Durumu

\begin{tabular}{lcc}
\hline Öğretim Türü & $\mathbf{f}$ & $\mathbf{\%}$ \\
\hline Normal Öğretim & 71 & 48,6 \\
İkinci Öğretim & 75 & 51,4 \\
TOPLAM & 146 & 100,0 \\
\hline
\end{tabular}

Tablo 2 incelendiğinde sınıf öğretmeni adaylarının yarıdan fazlasının $(\% 51,4)$ ikinci öğretim öğrencileri olduğu dikkat çekmektedir. Araştırmada öğretim türünün bir değişken olarak ele alınmasının temel sebebi öğrencilerin üniversiteye giriş puanlarına göre normal öğretim-ikinci öğretim olarak ayrılmasından kaynaklanmaktadır.

\section{Veri Toplama Aracı}

$\mathrm{Bu}$ araştırmada kullanılan ilk veri toplama aracı Watson-Glaser eleştirel Akıl Yürütme Gücü Testi, G. Watson ve M.E. Glaser tarafından (1964) Amerika Birleşik Devletleri'nde YM ve ZM adıyla iki paralel form halinde geliştirilmiştir. Watson-Glaser Eleştirel Akıl Yürütme Gücü Testi 100 madde ve beş boyuttan oluşmaktadır.

Çıkrıkçı (1992: 559-569) Watson-Glaser Eleştirel Akıl Yürütme Gücü Testi' nin YM formunun uyarlamasını yapmıştır. Araç eleştirel düşünmenin bazı önemli boyutlarını ölçmektedir. Bunlar: Çıkarsama Boyutu (Inference), Varsayımların Farkına Varma Boyutu (Recognition of Assumptions), Tümdengelim Boyutu (Deduction), Yorumlama Boyutu (Interpretation), Karşı Görüsslerin (tartışmaların) Değerlendirilmesi Boyutu (Evaluation of Arguments):

I. Çıkarsama (inference): 20 maddelik bu alt testte, testi yanitlayan kişiden metne dayanarak maddelerin doğruluk yanlışlık dereceleri hakkında karar vermeleri istenmektedir.

II. Varsayımlarm Farkına Varma (recognition of assumptions): Bu alt testte yapılan varsayımların verilen durumdan çıkartılıp çıkartılamayacağına karar verme gücü 16 madde ile ölçülmektedir.

III. Tümdengelim (deduction): 25 maddeden oluşan bu alt testte birbirini izleyen iki önermeden sonra verilen önermelerin ilk iki önermeyi izleyip izlemeyeceğine karar verme gücü ölçülmektedir. 
IV. Yorumlama (interpretation): 24 maddelik bu alt testte maddeler, kanıtları tartma, bir kısım veriden çıkarılan, mantıken doğru olduğu şüphe götürmez olan genellemelerle, doğruluğu şüpheli bulunan genellemeler arasında ayırım yapma yeteneği ölçülmektedir.

V. Tartışmaların Değerlendirilmesi (evaluation of arguments): 15 maddelik bu alt test ile tartışmaya açık bir soru ifadesini izleyen gerekçeli cevapların güçlü ve ya zayıf olduğuna karar verme gücü ölçülmektedir.

$\mathrm{Bu}$ araştırmada kullanılan ikinci veri toplama aracı Semiz (2009: 8892) tarafından geliştirilen "Etkinlikler için Eleştirel Düşünmeye Uygunluk Ölçeği" dir. Etkinliklerin eleştirel düşünmeye uygunluğunu ölçen veri toplama aracı iki bölümden oluşmaktadır: Kişisel bilgilerin yer aldığı birinci bölüm ve etkinliklerin eleştirel düşünmeye uygunluğunun değerlendirildiği ikinci bölüm. İkinci bölümde 42 soru bulunmaktadır. Ölçeğin faktör yapısını belirlemek amacıyla, faktör analizi yapılmıştır. Turgut ve Baykul (1992: 173)' un belirttiğine göre, faktör analizi, birden fazla değişkene bağlı bir değişkeni açıklamakta katkısı olan bağımsız değişkenlerin (faktörlerin), sayısını (uzayın boyutları sayısını) ve bu bağımlı değişkenin koordinatlarını (faktör yüklerini) bulmada başvurulan bir yöntemdir. Analiz sonuçlarına göre faktör yükü 0,30 ve 0,30 'dan büyük olanlar seçilmiş ve toplam " 42 " soru ölçekte yer almıştır. Cronbach's Alpha değeri hesaplanmış; soruların eleştirel düşünmeye uygunluğu için düzenlenmiş ölçeğin güvenirlik katsayısı 0,97 olarak hesaplanmıştır.

"Katılıyorum", "karasızım" ve "katılmıyorum" olmak üzere üçlü dereceleme ölçeğinin kullanıldığı veri toplama aracına verilen cevaplar, olumlu ifadeler için "katılıyorum: 3", kararsızım: 2" ve katılmıyorum: 1" seklinde, olumsuz ifadeler içinde tam tersi şekilde puanlarla kodlanmıştır. Toplam puanların aritmetik ortalamalarının karşılaştırılmasında soru ölçeğinden elde edilebilecek azami puan 126, asgari puan ise $42^{\prime}$ dir. Bu puanları değerlendirirken etkinlik ölçeği için "42-69" puan aralı̆̆ düşük, "7098" puan aralığ uygunluk aralığı olarak kabul edilmiştir.

\section{Bulgular}

$\mathrm{Bu}$ başlık altında araştırmanın alt problemlerine uygun olarak yapılan analizler verilmiştir.

Tablo 3'te "Etkinlikler için Eleştirel Düşünmeye Uygunluk Ölçeği" kullanılarak elde edilen verilerinin genel istatistiği sunulmuştur. 
Sosyal Bilimler Dergisi 225

Tablo 3: Sını Öğretmeni Adaylarının Toplam Puanlarının Genel İstatistiğ

\begin{tabular}{lc}
\hline & Ölçeğin Geneli \\
\hline$\overline{\mathrm{X}}$ & 86,84 \\
$\mathrm{~S}$ & 18,36 \\
Alınabilecek Asgari Puan & 42 \\
Alınan Asgari Puan & 42 \\
Alınabilecek Azami Puan & 126 \\
Alınan Azami Puan & 126 \\
\hline
\end{tabular}

Tablo 3 incelendiğinde 146 sınıf öğretmeni adayının ölçeğin tümünden aldıkları puanlar incelendiğinde 86,84 ortalama puana sahip oldukları görülmektedir. "70-98 puan aralığ1" orta düzey eleştirel düşünmeye uygunluk aralığını temsil ettiğinden sınıf öğretmeni adaylarının 4-5. sınıf sosyal bilgiler etkinliklerini eleştirel düşünmeye orta düzeyde uygun buldukları anlaşılmaktadır.

Tablo 4: Sını Öğretmeni Adaylarının 4. Sını Sosyal Bilgiler Ünitelerindeki Etkinlikleri Eleştirel Düşünme Açısından Genel Değerlendirme Sonuçları

\begin{tabular}{llcc}
\hline Öğrenme alanı & 4. Sınıf-Ünite & f & \% \\
\hline 1- Birey ve Toplum & Kendimi Tanıyorum & 9 & 6,2 \\
2- Kültür ve Miras & Geçmişimi Öğreniyorum & 32 & 21,9 \\
3- İnsanlar, Yerler ve Çevreler & Yaşadığımız Yer & 22 & 15,1 \\
4- Üretim, Dağıtım ve & Üretimden Tüketime & 24 & 16,4 \\
Tüketim & & \\
5- Bilim, Teknoloji ve Toplum & İyi ki Var & 12 & 8,2 \\
6- Gruplar, Kurumlar ve & Hep Birlikte & 15 & 10,3 \\
Sosyal Örgütler & & & \\
7- Güç, Yönetim ve Toplum & İnsanlar ve Yönetim & 24 & 16,4 \\
8- Küresel Bağlantılar & Uzaktaki Arkadaşlarım & 8 & 5,5 \\
Toplam & & 146 & 100 \\
\hline
\end{tabular}

4. sınıf Sosyal Bilgiler ünitelerinin hangisinin etkinliklerinin eleştirel düşünmeyi daha çok desteklediği sorusuna verilen yantlar incelendiğinde sınıf öğretmeni adaylarının \%21,9'u “Geçmişimi Öğreniyorum” ünitesinin etkinliklerinin eleştirel düşünmeyi diğer ünite etkinliklerinden daha çok eleştirel düşünmeyi destekler olarak değerlendirmiştir. Onu sırasıyla 
"Üretimden Tüketime”, “Güç, Yönetim ve Toplum” ünitelerinin etkinlikleri izlemiştir. Sınıf öğretmeni adaylarının \%5,5'i ise "Uzaktaki Arkadaşlarım" ünitesinin etkinliklerini diğer ünite etkinliklerinden daha çok eleştirel düşünmeyi destekler olarak değerlendirmiştir. Genel olarak bakıldığında tarih, coğrafya ve vatandaşlık alanlarıyla ilgili ünite etkinliklerinin sınıf öğretmeni adaylarınca diğer ünitelerden daha çok eleştirel düşünmeyi desteklediği ortaya çıkmıştır.

Tablo 5: Sını Öğretmeni Adaylarının 5. Sinıf Sosyal Bilgiler Ünitelerindeki Etkinlikleri Eleştirel Düşünme Açısından Genel Değerlendirme Sonuçları

\begin{tabular}{llcc}
\hline Öğrenme alanı & 5. Sınıf-Ünite & f & \% \\
\hline 1- Birey ve Toplum & Haklarımı Öğreniyorum & 14 & 9,6 \\
2- Kültür ve Miras & Adım Adım Türkiye & 28 & 19,2 \\
3- İnsanlar, Yerler ve Çevreler & Bölgemizi Tanıyalım & 34 & 23,3 \\
4-Üretim, Dağıtım ve Tüketim & Ürettiklerimiz & 11 & 7,5 \\
5- Bilim, Teknoloji ve Toplum & Gerçekleşen Düşler & 12 & 8,2 \\
6- Gruplar, Kurumlar ve Sosyal & Toplum İçin Çalışanlar & 10 & 6,9 \\
Örgütler & & & \\
7- Güç, Yönetim ve Toplum & Bir Ülke Bir Bayrak & 26 & 17,8 \\
8- Küresel Bağlantılar & Hepimizin Dünyası & 11 & 7,5 \\
Toplam & & 146 & 100 \\
\hline
\end{tabular}

5. sınıf Sosyal Bilgiler ünitelerinin hangisinin etkinliklerinin eleştirel düşünmeyi daha çok desteklediği sorusuna verilen yanıtlar incelendiğinde sınıf öğretmeni adaylarının \%23,3'ü "Bölgemizi Tanıyalım" ünitesinin etkinliklerinin eleştirel düşünmeyi diğer ünite etkinliklerinden daha çok eleştirel düşünmeyi destekler olarak değerlendirmiştir. Onu sırasıyla "Adım Adım Türkiye", "Bir Ülke Bir Bayrak" ünitelerinin etkinlikleri izlemiştir. Sınıf öğretmeni adaylarının \%7,5'i ise "Ürettiklerim" ile "Hepimizin Dünyası" ünitelerinin etkinliklerini diğer ünite etkinliklerinden daha çok eleştirel düşünmeyi destekler olarak değerlendirmiştir. Genel olarak bakıldığında 4. sınıf ünitelerinin etkinliklerinde olduğu gibi 5. Sınıf ünitelerinde de coğrafya, tarih ve vatandaşlık alanlarıyla ilgili ünite etkinliklerinin sınıf öğretmeni adaylarınca diğer ünitelerden daha çok eleştirel düşünmeyi desteklediği ortaya çıkmıştır. 
Sosyal Bilimler Dergisi 227

Tablo 6: Sınıf Öğretmeni Adaylarmın Toplam Puanlarının "Cinsiyet" Değişkenine Göre Farklılı̆̆ İçin t-Testi Sonuçları

\begin{tabular}{ccccccc}
\hline & Cinsiyet & $\mathbf{N}$ & $\overline{\mathbf{x}}$ & $\mathbf{S}$ & $\mathbf{t}$ & $\mathbf{p}$ \\
\hline \multirow{2}{*}{ Toplam Puan } & $\mathrm{K}$ & 74 & 85,05 & 17,86 & & \\
& $\mathrm{E}$ & 72 & 88,68 & 18,81 & & 0,234 \\
\hline
\end{tabular}

${ }^{*} \mathrm{p}>0.05, \mathrm{sd}=144$

Tablo 6 incelendiğinde ölçeğin tamamı için sınıf öğretmeni adaylarının puanlarında "cinsiyet" değişkeni açısından anlamlı bir farklılık ortaya çıkmadığı görülmektedir. Kız öğrencilerin sosyal bilgiler etkinliklerinin eleştirel düşünmeye uygunluğuna dair toplam puanları 85,05 ortalamaya sahipken, erkek öğrencilerin puanları 88,68 ortalamaya sahiptir. Bu durum erkek sınıf öğretmeni adaylarının, etkinlikleri kız sınıf öğretmeni adaylarına göre anlamlı düzeyde olmasa da eleştirel düşünmeye daha uygun bulduklarını göstermektedir.

Sınıf öğretmeni adaylarının toplam puanlarının "öğretim türü" değişkenine göre farklılığı için t-Testi sonuçları Tablo 7 'de sunulmuştur.

Tablo 7: Sinıf Öğretmeni Adaylarmın Toplam Puanlarmın "Öğretim Türü" Değişkenine Göre Farklılı̆̆ı İçin t-Testi Sonuçları

\begin{tabular}{ccccccc}
\hline & Öğretim Türü & $\mathbf{N}$ & $\overline{\mathbf{x}}$ & $\mathbf{S}$ & $\mathbf{t}$ & $\mathbf{p}$ \\
\hline Toplam & Normal Öğretim & 71 & 88,45 & 17,76 & \multirow{2}{*}{1,032} & \multirow{2}{*}{0,304} \\
Puan & İkinci Öğretim & 75 & 85,32 & 18,90 & & \\
\hline
\end{tabular}

${ }^{*} \mathrm{p}>0.05, \mathrm{sd}=144$

Tablo 7 incelendiğinde ölçeğin tamamı için sınıf öğretmeni adaylarının puanlarında "öğretim türü" değişkeni açısından anlamlı bir farklılık ortaya çıkmadığı görülmektedir. Normal öğretim öğrencilerinin sosyal bilgiler etkinliklerinin eleştirel düşünmeye uygunluğuna dair toplam puanları 88,45 ortalamaya sahipken, ikinci öğretim öğrencilerinin puanları 85,32 ortalamaya sahiptir. Bu durum normal öğretim gören sınıf öğretmeni adaylarının, etkinlikleri ikinci öğretim gören sınıf öğretmeni adaylarına göre anlamlı düzeyde olmasa da eleştirel düşünmeye daha uygun bulduklarını göstermektedir.

Literatür incelendiğinde sınıf öğretmeni adaylarının sosyal bilgiler etkinliklerinin eleştirel düşünmeye uygunluğuna dair bir çalışmaya rastlanılamadığından sonuçları karşılaştırma imkânı bulunamamıştır. 


\section{Sonuçlar}

Çanakkale Onsekiz Mart Üniversitesi Eğitim Fakültesi İlköğretim Bölümü Sınıf Öğretmenliği ABD 3. sınıflarında öğrenim gören 146 öğretmen adayının katıldığı araştırma sonucunda elde edilen sonuçlar şunlardır:

- Anabilim Dalında öğrenim gören 172 öğretmen adayının WatsonGlaser Eleştirel Akıl Yürütme Gücü Testi'nden 146'sı 50 puan ve üzeri puan almışlardır.

- Sınıf öğretmeni adaylarının 4-5. sınıf sosyal bilgiler etkinliklerini eleştirel düşünmeye orta düzeyde uygun bulmaktadırlar.

- Sınıf öğretmeni adaylarının \%21,9'u 4. sınıf “Geçmişimi Öğreniyorum" ünitesinin etkinliklerinin eleştirel düşünmeyi diğer ünite etkinliklerinden daha çok eleştirel düşünmeyi destekler olarak değerlendirmiştir.

- Sınıf öğretmeni adaylarının \%23,3'ü 5. sınıf "Bölgemizi Tanıyalım" ünitesinin etkinliklerinin eleştirel düşünmeyi diğer ünite etkinliklerinden daha çok eleştirel düşünmeyi destekler olarak değerlendirmiştir.

- Sınıf öğretmeni adaylarının puanlarında "cinsiyet" değişkeni açısından anlamlı bir farklılık ortaya çıkmadığı görülmüştür.

- Sınıf öğretmeni adaylarının puanlarında "öğretim türü" değişkeni açısından da anlamlı bir farklılık ortaya çıkmadığı görülmüştür.

Eğitimin amacl, sürekli düşünen, düşüncelerinin en uygun şekilde hayata geçirerek hem bireysel hem de toplumsal gelişim sağlayan etkili bireyler yetiştirmektir. Bu da okullarda eleştirel düşünmenin öğretilmesine dönük etkinliklere yer verilmesi gerektiğini (Kürüm, 2002) göstermektedir.

\section{Kaynaklar}

Al-Weher, M. (2004). The effect of a training course based on constructivism on student teachers' perceptions of the teaching/learning process. Asia-Pacific Journal of Teacher Education. 32(2), 169-184.

Balım, A.G., Kesercioğlu, T., İnel, D., \& Evrekli, E. (2009). Fen öğretmen adaylarının yapılandırmacı Yaklaşıma yönelik görüşlerinin farklı Değişkenler açısından incelenmesi. Ondokuz Mayıs Üniversitesi Eğitim Fakültesi Dergisi, 27, 55-74.

Coşkun, B. (2008). İlköğretim 5. Sınıf Türkçe Dersi Öğrenci Çalışma Kitaplarının ve Ders Kitaplarının Çeşitli Açılardan İncelenmesi. 
Sosyal Bilimler Dergisi 229

(Yayımlanmamış Yüksek Lisans Tezi), Çukurova Üniversitesi, Adana.

Çıkrıkçı, N. (1992).Watson-Glaser Eleştirel Akıl Yürütme Gücü Ölçeğinin (Form YM) Lise Öğrencileri Üzerindeki Ön Deneme Uygulamaları. Ankara Üniversitesi Eğitim Bilimleri Fakültesi Dergisi, 25 (2), 559-569.

Demir, M. K. (2006). İlköğretim Dördüncü ve Beşinci Sınıf Öğrencilerinin Sosyal Bilgiler Derslerinde Eleştirel Düşünme Düzeylerinin Çeşitli Değişkenler Açısından İncelenmesi, (Yayınlanmamış Doktora Tezi), Gazi Üniversitesi, Ankara.

Hendry, G. D., Frommer, M., \& Walker, R. A. (1999). Constructivism and problem-based learning. Journal of Further and Higher Education, 23(3), 359-371.

Kroll, L. R. (2004). Constructing constructivism: How student-teachers construct ideas of development, knowledge, learning, and teaching. Teachers and Teaching: Theory and Practice. 10(2), 199-221.

Kürüm, D. (2002). Öğretmen Adayların Eleştirel Düşünme Gücü", (Yayımlanmamış Yüksek Lisans Tezi), Anadolu Üniversitesi, Eskişehir.

MEB. (2005). İlköğretim 1, 2 ve 3. Sınıflar Hayat Bilgisi Dersi Öğretim Programı ve Kılavuzu. Milli Eğitim Yayınları, Ankara.

Oğuz, A. (2004). Yükseköğretimde yapılandırmacı öğrenme ortamları. Eurasian Journal of Educational Research. 17, 188-197.

Özden, Y. (2005). Öğrenme ve öğretme. Ankara: PegemA Yayıncılık.

Phillips, D. C. (1995). The good, the bad, and the ugly: The many faces of constructivism. Educational Researcher. 24(7), 5-12.

Semiz, A. (2011). 4. ve 5. Sınıf Ders Kitaplarındaki Soruların Eleştirel Düşünmeye Uygunluğu ve Ders Etkinlikleri Üzerine Öğretmen Görüşleri. (Yayınlanmamış Yüksek Lisans Tezi). Çanakkale Onsekiz Mart Üniversitesi, Çanakkale.

Taber, K. S. (2000) Chemistry lessons for universities?: A review of constructivist ideas. University Chemistry Education. 4(2), 63-72.

Temur, T. (2007). Yeni Türkçe Öğretim Programları. (Ed.'ler. A.Kırkkılıç ve H.Akyol). İlköğretimde Türkçe Öğretimi, (351-394) Ankara: Pegem A Yayıncilik. 